\title{
Comparison between inflammatory profiles during infections with Staphylococcus aureus and Escherichia coli in a murine air pouch model
}

\author{
Comparação entre os perfis inflamatórios durante infecções com Staphylococcus aureus e \\ Escherichia coli em um modelo murino de bolsão de ar
}

\author{
P. A. Guerra ${ }^{1}$; A. F. Queiroz ${ }^{1}$; L. L. Lima ${ }^{1}$; I. S. Pereira ${ }^{1}$; D. P. Santos ${ }^{1}$; T. B. \\ Figueiredo $^{1}$; L. M. Marques ${ }^{2}$; R. A. A. Silva ${ }^{1}$ \\ ${ }^{1}$ Laboratório de Histopatologia, Universidade Federal da Bahia, Campus AnísioTeixeira, 45000-000, Vitória da \\ Conquista-Ba, Brazil. \\ ${ }^{2}$ Núcleo de Biointegração, Universidade Federal da Bahia, CampusAnísioTeixeira, 45000-000,Vitória da \\ Conquista-Ba,Brazil.
}

robson.amaro@gmail.com;

(Received April 28 $8^{\text {th }}, 2015$; accepted June $17^{\text {th }}, 2015$ )

\begin{abstract}
Staphylococcus aureus along with Escherichia coli is the most common and one of the oldest human symbiotic bacteria. The Gram- positive bacterium, Staphylococcus aureus, is an important human pathogen that causes a wide variety of diseases, ranging from minor skin infections to life-threatening infections, well as some strains the Escherichia coli, a gram-negative bacterium. In this way, the aim of this study was evaluate inflammatory profiles during infections by Staphylococcus aureus and Escherichia coli in a murine air pouch model. Twelve BALB/c mice had a solution of sterile air inoculated into their dorsal region and were divided into three groups. One group of animals was infected with $S$. aureus, another group with $E$. coli and a third group received saline. Twenty-four hours after infection, systemic responses were evaluated by leukocyte counts in the blood, air pouch lavage and bone marrow. Samples of skin were evaluated by morphometry. The IFN- $\gamma$ present in the air pouch lavage, homogenized spleen and bone marrow, was evaluated by ELISA. The results indicate that the group $S$. aureus promoted higher cell recruitment to the site of inflammation, confirmed by histopathological analysis. The animals infected with $E$. coli showed difference in the total blood leucocyte cells evaluation. The dosage of IFN- $\gamma$ for the study groups was larger than the reference given by the control group. In synthesis, $S$. aureus induced greater local recruitment of leukocytes.
\end{abstract}

Keywords: Staphylococcus aureus, Escherichia coli, air pouch.

Staphylococcus aureus juntamente com Escherichia coli é a mais comum e uma das mais antigas bactérias simbióticas humanas. A bactéria Gram-positiva, Staphylococcus aureus, é um importante agente patogénico humano que causa uma grande variedade de doenças, desde infecções menores da pele até infecções que ameaçam a vida, bem como algumas estirpes de Escherichia coli, uma bactéria gramnegativa. Deste modo, o objetivo deste estudo foi avaliar os perfis inflamatórios durante infecções por Staphylococcus aureus e Escherichia coli, em um modelo de bolsão de ar murino. Doze camundongos $\mathrm{BALB} / \mathrm{c}$ tiveram uma solução de ar estéril inoculado em sua região dorsal e foram divididos em três grupos. Um grupo de animais foi infectado com $S$. aureus, outro com E. coli e um terceiro grupo recebeu solução salina. Vinte e quatro horas após a infecção, as respostas sistêmicas foram avaliadas por contagem de leucócitos no sangue, no lavado do bolsão de ar e na medula óssea. As amostras de pele foram avaliadas por morfometria. O IFN- $\gamma$ presente no lavado do bolsão de ar, homogeneizado do baço e da medula óssea, foi avaliado por ELISA. Os resultados indicam que o grupo infectado com $S$. aureus promoveu um maior recrutamento de células para o local da inflamação, confirmado por análise histopatológica. A infecção com E. coli apresentou diferença na avaliação total de leucócitos no sangue. A dosagem de IFN- $\gamma$ para os grupos de estudo foi maior do que a referência fornecida pelo grupo controle. Em síntese, S. aureus induziu um maior recrutamento local de leucócitos.

Palavras chaves: Staphylococcus aureus, Escherichia coli, Bolsão de ar. 


\section{INTRODUCTION}

Staphylococcus aureus and Escherichia coli are among the most common species of grampositive and gram-negative bacteria, respectively, that induces a variety of clinical diseases. Humans are a natural reservoir for both, and asymptomatic colonization is far more common than infection [1]. S. aureus has the unique ability to cause a wide range of infections and syndromes, including skin and soft tissue infections, food borne illness, toxic shock syndrome, bacteremia, sepsis, endocarditis, osteomyelitis, necrotizing fasciitis, and pneumonia. The comprehension of the interaction between $S$. aureus and human neutrophils is a critical step in understanding the establishment of infection [2].

Gram-positive bacteria have a thick and rigid cell wall consisting of up to 50 layers of peptidoglycan along with teichoic acid, lipoteichoic acids, lipoproteins and other constituents whereas Gram-negative bacteria have a very thin peptidoglycan layer and an outer membrane that contains lipopolysaccharide and lipoproteins. Lipopolysaccharide, peptidoglycan, lipoproteins, and lipotechoic acids are recognized by pattern recognition receptors (PPRs), many of which are expressed on different subsets of antigen presenting cells [3].

Usually, E. coli forms a beneficial symbiotic relationship with its host and plays important roles in promoting microbial stability and maintenance of the normal intestinal homeostasis [4]. Some strains of $E$. coli can diverge from their commensal cohorts, taking on a more pathogenic behavior. These strains acquire specific virulence factors which confer an increased ability to adapt to new niches and allow the bacteria to increase their ability to cause a broad spectrum of diseases [5].

The relationship between colonization and the development of infections is complex. Successful establishment of infection by bacterial pathogens requires adhesion to host cells, colonization of tissues, and, in certain cases, cellular invasion, followed by intracellular multiplication, dissemination to other tissues, or persistence [6]. Thus, the innate immune system comprises the immediate defense mechanisms to protect the host against infection. A first step towards the eradication of invading microorganisms is the active recruitment of polymorphonuclear leukocytes to the site of infection by chemotaxis [7].

Inflammation is a fundamental process that protects organisms by removing or neutralizing injurious agents. A key event in the inflammatory response is the localized recruitment of various leukocyte subsets. Neutrophils or polymorphonuclear leukocytes (PMNs) are the most abundant of all leukocytes and are essential for host defense against invading pathogenic microbes [8]. PMNs are terminally differentiated innate immune cells and following maturation in bone marrow are released into circulation [9]. Neutrophils are short-lived granulocytes derived from pluripotent hematopoietic stem cells in the bone marrow [10]. Although granulocytes and lymphocytes are derived from similar pluripotent stem cells, granulopoiesis is distinct from that of lymphopoiesis, requiring a unique set of transcriptional regulators that facilitate the maturation of granule proteins and surface markers/receptors characteristic of granulocytes $[11,12]$.

The majority of hematopoiesis is devoted to granulopoiesis, as nearly $60 \%$ of leukocytes within the bone marrow are granulocyte precursors [10]. Early in the neutrophil differentiation process, cells develop phagocytic capacity followed by development of oxygen-dependent microbicidal activity, increased adhesiveness, cell motility, chemotactic response, and other cell type-specific traits, proceeding through a well-characterized, carefully regulated, multi-step progression into mature neutrophils [13].

The importance of neutrophils in S. aureus infections cannot be understated; neutrophils are the first to arrive at the local infectious site, migrate out of the vasculature, and attempt to eradicate the pathogen through defenses that include oxidant production, as well as the release of proteases, defensins and various other toxins $[14,15]$. Therefore, early neutrophil recruitment is critical to protect the host from the bacterial infection [14].

Macrophages are a major component of the mononuclear phagocyte system that consists of closely related cells of bone marrow origin, including blood monocytes, and tissue macrophages. In inflammation, macrophages have three major functions; antigen presentation, phagocytosis, and immunomodulation through production of various cytokines and growth 
factors. Macrophages play a critical role in the initiation, maintenance, and resolution of inflammation [16].

They are activated and deactivated in the inflammatory process. Activation signals include granulocyte-monocyte colony stimulating factor, tumor necrosis factor $\alpha$, bacterial lipopolysaccharide, extracellular matrix proteins and cytokines with interferon $\gamma$, produced mainly by $\mathrm{T}$ lymphocytes and NK cells, which can contribute to the acute inflammatory response, and particularly in chronic, increasing the number of phagocytic cells to the site of inflammation. Macrophages participate in the repair of injured tissue, and serve as a bridge between the innate and adaptive arms of immunity [17]. Distinguishing among different types of inflammation is critical for understanding relative fitness costs to the host. Importantly, inflammation and its sequelae vary both spatially and temporally. Inflammation normally begins in a localized area, but depending upon the severity of the infection/wound, it can spread rapidly to the periphery [18].

Inflammation and biological processes intensively studied since the early nineteenth century, being a physiological response triggered by tissue injury or antigenic stimuli and which can often be harmful to the body. The inherent ability of the innate immune system to respond to a large number of external agents is mediated by its ability to recognize highly conserved structures shared by many pathogens $[19,20]$. In this way, the aim of this study was evaluate inflammatory profiles during infections Staphylococcus aureus and Escherichia coli in a murine air pouch model.

\section{MATERIAL AND METHODS}

\subsection{Ethics Statement}

The Ethics Committee of Animal Use - CEUA, IMS / CAT / UFBA approved the experimental design and the use of all animals. Protocol 013/2014.

\subsection{Animals}

Balb/c mice with 6-8 weeks of age from the facilities of the Instituto Multidisciplinar em Saúde da Universidade Federal da Bahia, were kept at a room temperature $\left(23^{\circ} \mathrm{C}\right)$ and free access to food and water.

\subsection{Microorganisms Used}

The Escherichia coli (ATCC 25922) in this study used provided by the Institute National of Control Quality in Health - INCQS (Fundação Oswaldo Cruz) and Staphylococcus aureus MRSA (ATCC 43300) provided by the Instituto de Ciências Biomédicas ICB-USP.

\subsection{Experimental design for infection and formation of air pouch}

\section{Methicillin-resistant Staphylococcus aureus culture and Escherichia coli}

A sample of the strain of Staphylococcus aureus was cultured in BHI culture (brain heart infusion) for 24 hours at $37{ }^{\circ} \mathrm{C}$, as well as a sample of lyophilized Escherichia coli was reactivated in TSB for 4 hours and subsequently McConkey cultured for 24 hours. To perform the quantization, many $S$. aureus formed colonies and E. coli were transferred to $5 \mathrm{ml}$ of sterile saline. The bacterial load was measured by spectrophotometer at $660 \mathrm{\eta m}$ length for Staphylococcus aureus and length of $630 \eta \mathrm{m}$ for Escherichia coli, according to the Mcfarland (1907) [21] standard. Following, dilutions in saline were performed in order to achieve the bacterial load of $10^{7}$, for both bacteria. 


\section{Protocol for infection}

The total of 12 animals was divided into three groups containing four mice per group, with the following proposals: The group 1 received saline; the group 2 was infected with MRSA; the group 3 was infected with E. coli. The first one was the control group and the groups 2 and 3 represented the experimental groups. The mice were lightly anesthetized with $100 \mu \mathrm{L}$ of the solution of ketamine $(40 \mathrm{mg} / \mathrm{kg})$ and xylazine $(10 \mathrm{mg} / \mathrm{kg})$ by intraperitoneal injection. The respective groups received subcutaneously in the dorsal region of $100 \mu 1$ sterile saline, $100 \mu 1$ of saline with $10^{7} \mathrm{CFU}$ MRSA and the third group $100 \mu \mathrm{l}$ of saline with $10^{7} \mathrm{CFU}$ Escherichia coli followed subcutaneous injection of $3 \mathrm{ml}$ sterile air. The animals were euthanatized 24 hours after the formation of the air pouch.

\section{Obtaining blood}

After euthanasia, the animals were placed on a flat surface in a supine position, with blood sampling carried out by the upper section of the portal vein followed by preparation of the blood smear stained with Panoptic (RenyLAb) for morphological analysis of leukocytes. The total leukocyte quantification was performed in Neubauer hemocytometer.

\section{Determination of cell influx into the air pouch}

The air pouch was washed 5 times with a total volume of $5 \mathrm{ml}$ of saline. The lavage was centrifuged at $300 \mathrm{~g}$ for 10 minutes at $4{ }^{\circ} \mathrm{C}$. The supernatant obtained after centrifugation was then separated for subsequent detection of cytokines. The pellets formed were resuspended in $200 \mu \mathrm{l}$ sterile saline and total leukocyte cells were performed in Neubauer hemocytometer. Cell morphology was evaluated by Cytospin and stained with Panoptic.

\section{Measurement IFN- $\gamma$}

INF- $\gamma$ was measured using ELISA capture following the protocol suggested by the manufacturer (INVITROGEN ${ }^{\mathrm{TM}}$ - LIFE TECHNOLOGIES). The samples tested were obtained from homogenized spleen, bone marrow and lavage of the air pouch.

\subsection{HISTOLOGICAL ANALYZES}

\section{Morphometric analysis of histological sections of skin}

Dorsal skin samples were included in paraffin and sectioned to a thickness of $4 \mu \mathrm{m}$ and stained with hematoxylin and eosin ( $\mathrm{H} \& \mathrm{E})$. For morphometric analysis was used the software Image-Pro being performed capturing 5 images of 12 samples evaluated in the experiment, in the $20 \mathrm{X}$. ImageJ software was used for determine the area and total count of cells.

\subsection{STATISTICAL TREATMENTS}

Data were evaluated using ANOVA and the Kruskal-Wallis test followed by Dunn's post-test using version 5.0, GraphPad Software. Statistical differences were considered significant at $p$ values $<0.05$.

\section{RESULTS}

\section{Increase in the number of circulating leukocytes}

To assess the systemic response, the total and differential blood cell counts were performed. Twenty-four hours after infection we observed that the numbers of total leukocytes (Figure 1A) 
were increased in mice infected with $S$. aureus or with E. coli compared with the control group. Predominantly neutrophils, macrophages and lymphocytes and, to a lesser extent, contributes to the flow of leukocytes observed within the space forming the air pouch. As noted in the differential counts (Figure 1B), the numbers of neutrophils and monocytes of animal study groups were comparable to the control group. When evaluated the total count of bone marrow leukocytes (Figure 2) S. aureus and control groups showed comparable numbers of cells.

A

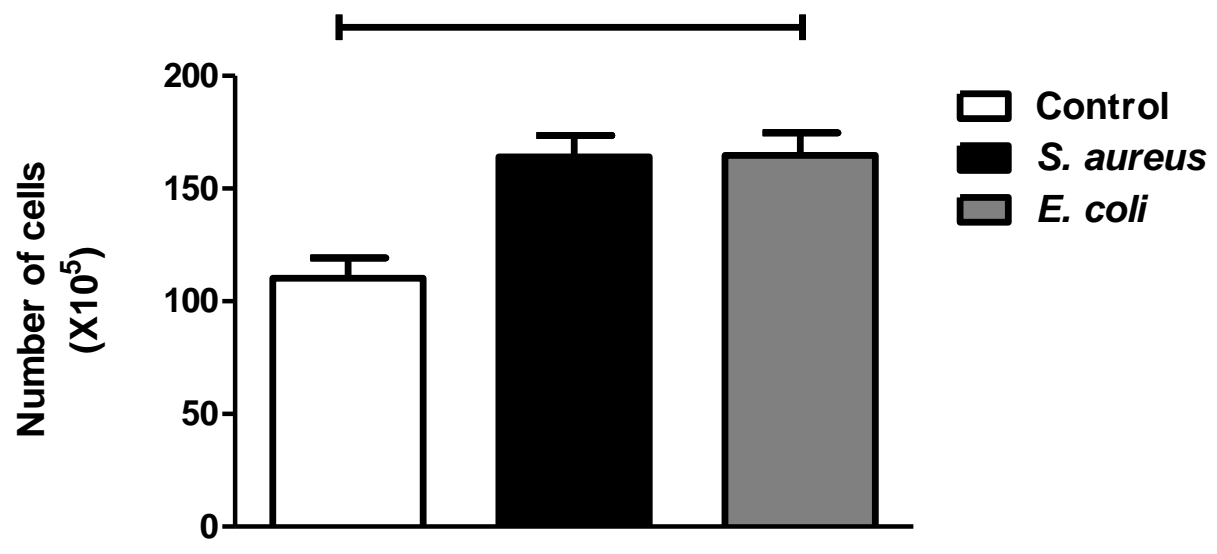

B

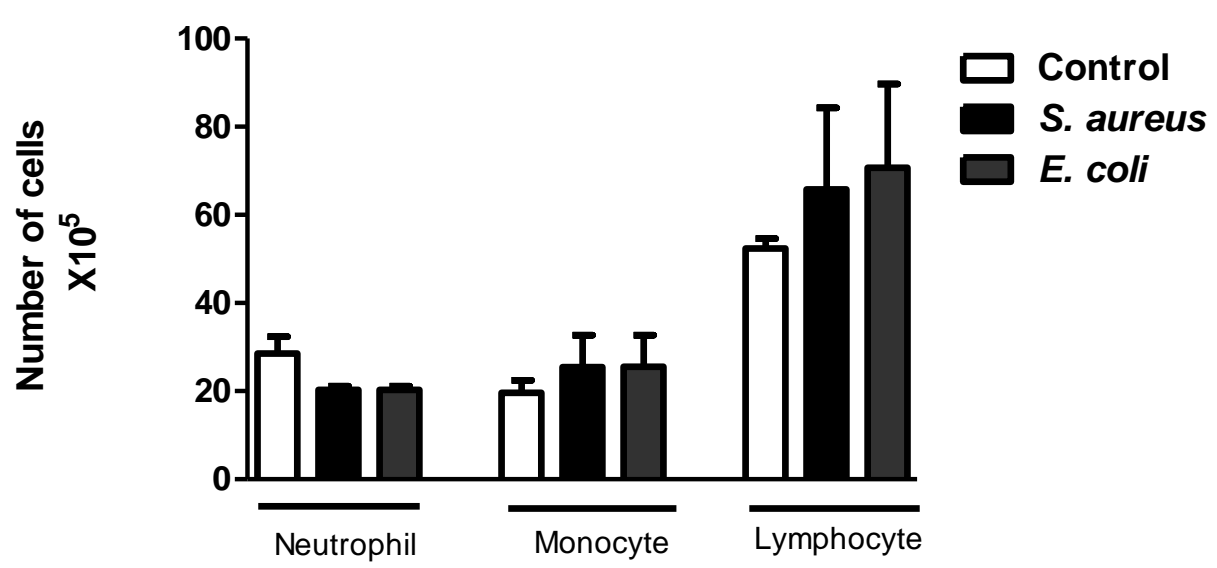

Figure 1-Determination of the systemic response. A. Total leukocytes. B. Leukocyte count differential. $n=12 . * p<0.05$. 


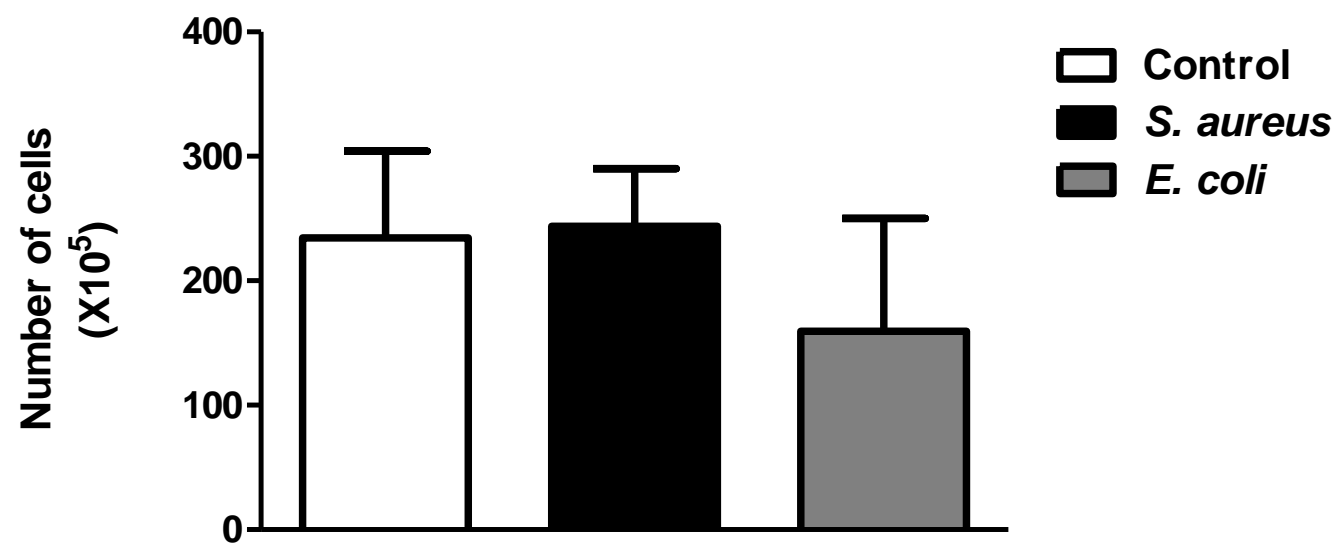

Figure 2-Recruitment of hematopoietic cells. $n=12$.

\section{Staphylococcus aureus infection induces an increased recruitment of leukocytes}

The recruitment of cells to the local inflammatory site was carried out by a morphometric analysis of skin samples from the air pouch. Through the Software Image Pro, twenty four hours after infection was possible to visualize a larger cell infiltrate in the group infected with $S$. aureus (Figure 3A). The ImageJ Software determined the area in $\mu^{2}$ and the total cell count (Figure 3B), which confirmed the higher number of leukocytes in $S$. aureus group when compared to the control group and the group E. coli. In the experimental data, the present total cell count in lavage is showed in the (Figure 4A).

$\mathbf{A}$

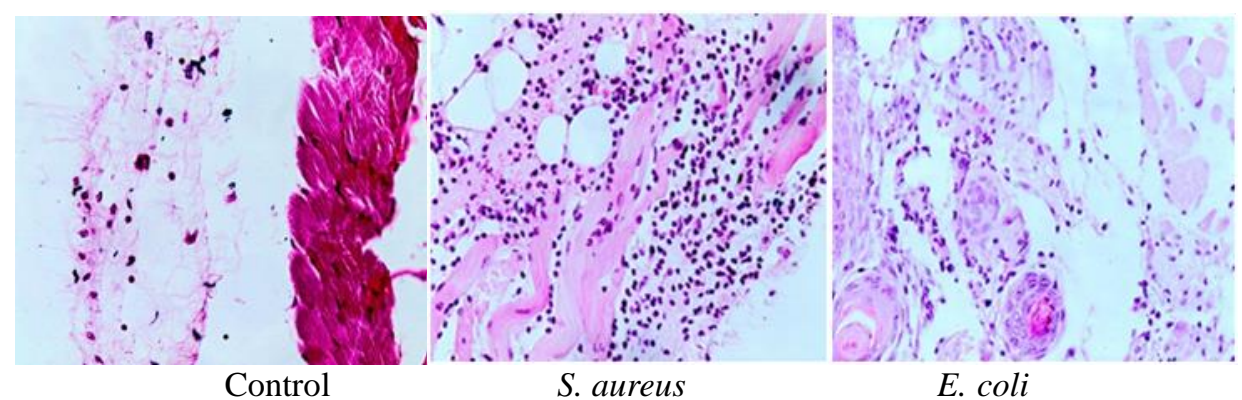

B

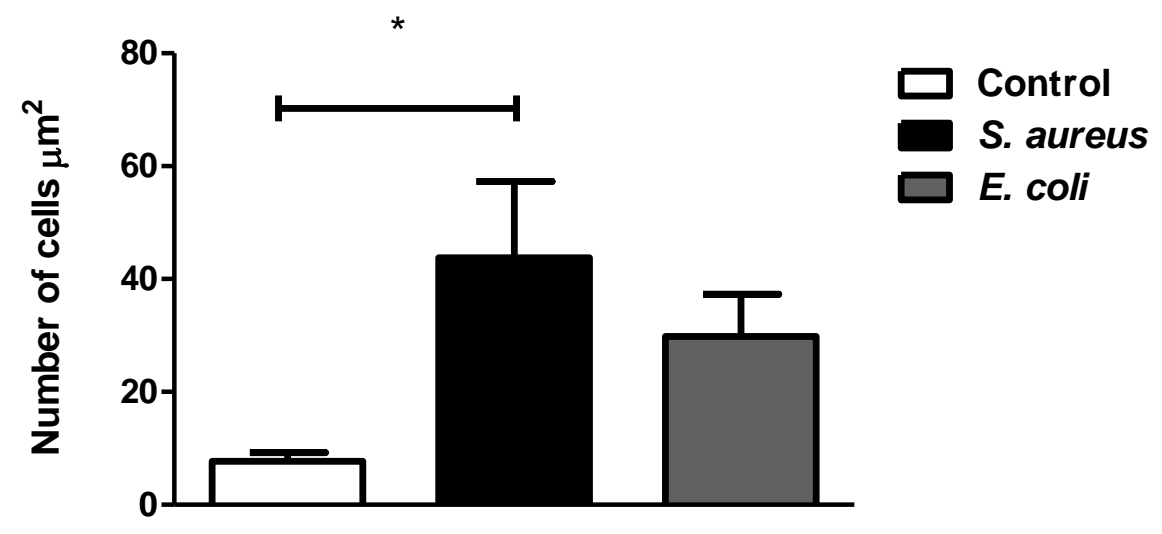

Figure 3 - Histology features. A. Histopathological analysis. B. Total count of cells in the tissue. $n=12 . *_{p}<0.05$ 
To emphasize the importance of migration of neutrophils and macrophages involved in the process of recognition and response to pathogenic agent during the first twenty four hours to the site of infection, differential cell counts (Figure 4B) of these leukocytes were performed. Both groups of study had a larger number of cells compared to the control group. Some sites are responsible for the modulation of the inflammatory response, among them the spleen, so we evaluated the INF- $\gamma$ measurement (Figure 5), the air pouch lavage, spleen and bone marrow, the data obtained allowed us to observe that both the group $S$. aureus as the E. coli group presented above the estimated values for the control group.

A

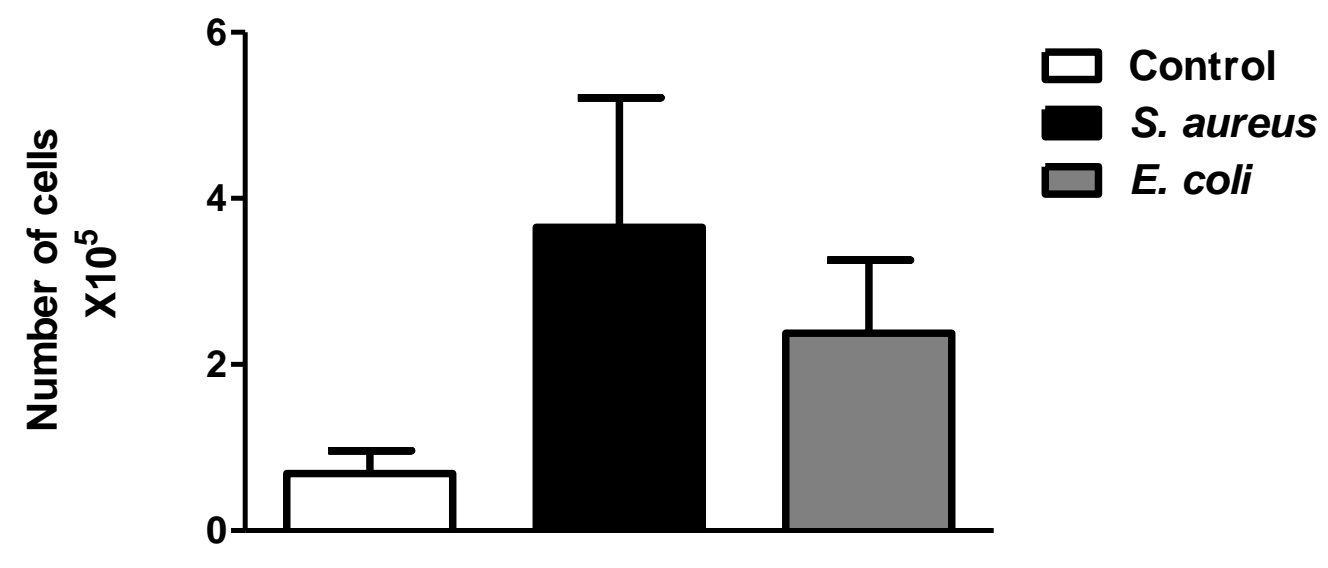

B

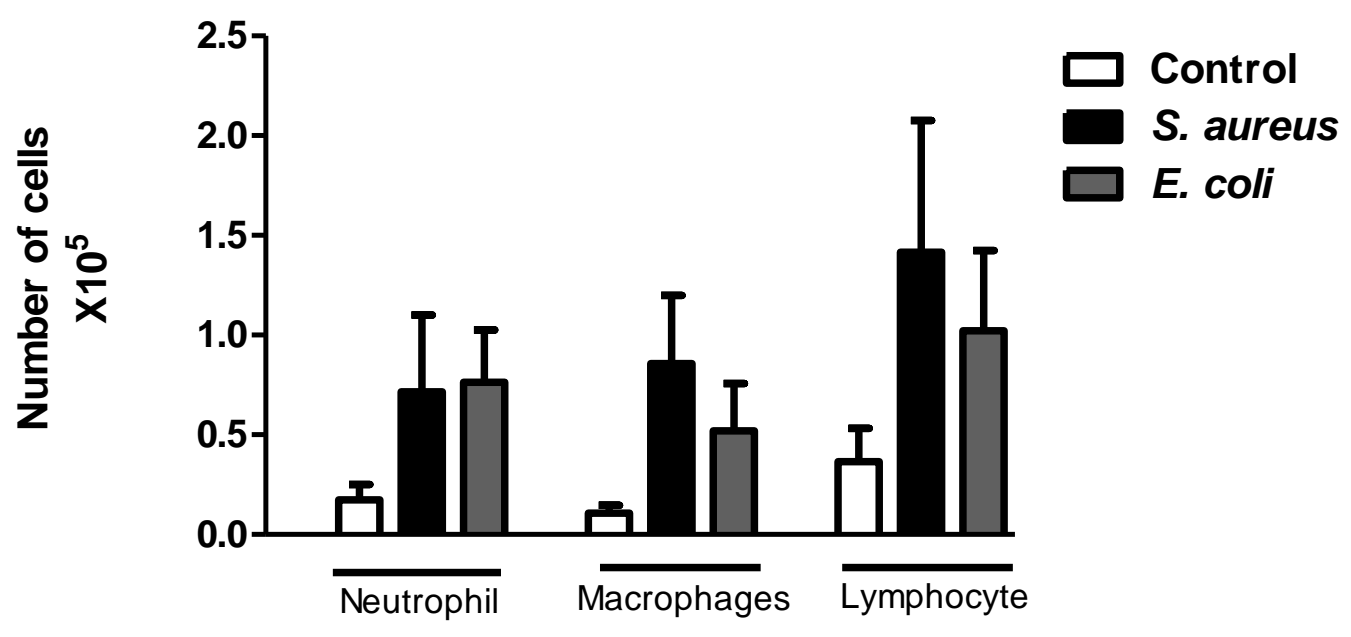

Figure 4- Determination of cell influx into the air pouch. A. Total leukocyte cell counts. B. The differential leucocyte cell counts. $n=12$. 


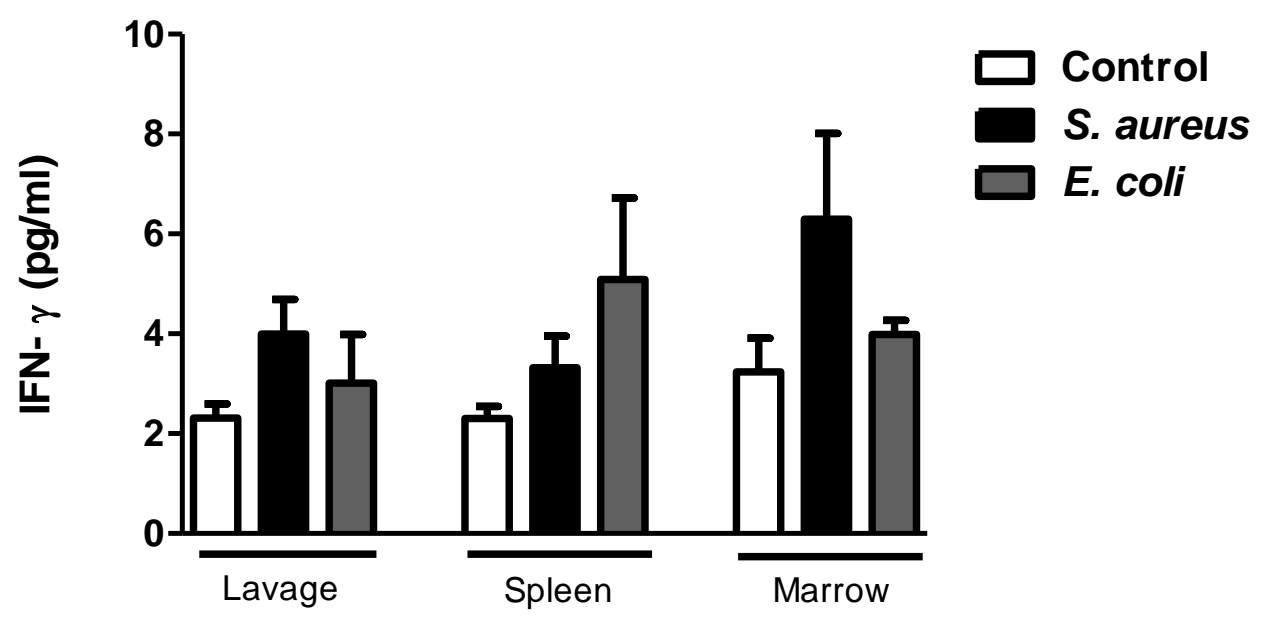

Figure 5- IFN- $\gamma$ production after stimulation with respective groups of $100 \mu$ l of sterile saline, $100 \mu \mathrm{l}$ with $10^{7}$ MRSA or $100 \mu$ l of $10^{7}$ Escherichia coli, for 24 hours. Bone marrow lavages and spleen macerated were evaluated. $n=12$.

\section{DISCUSSION}

This study demonstrates that gram-positive and gram-negative bacteria differ from inducing recruitment of leukocytes to the inflammatory site. The gram-positive and gram-negative evolutionarily were separated and developed in parallel for a very long period of time and acquired distinct structures like cell wall [22]. Teichoic and lipoteichoic acids unique structures are present in gram-positive while the lipopolysaccharide is a constituent of the outer cell wall of gram-negative bacteria. Both structures exert stimulatory effects on the immune system [23].

In our study, the experimental data indicate that $E$. coli, twenty-four hours after infection, showed a higher number of circulating leucocytes. The difference in total cell counts, blood smears, when compared to the control group, is probably related to the presence of lipopolysaccharide. This constituent has an effect on the release of cytokines in various cell types, leading to an acute inflammatory response, activating a cascade transcription factors and plays a crucial role in the regulation of genes involved in innate immunity [24]. The production of inflammatory mediator's results in the rapid recruitment of monocytes and neutrophils to the inflammatory site related to bacterial clearance, as observed in differential leukocyte cell counts presented in the blood of infected groups by $S$. aureus or E. coli.

The inflammatory response has been designed as important to resolve the infection, however, affects the target organ perfusion, and increases tissue damage. The infiltration of neutrophils and macrophages in different organs is a hallmark of inflammation [25]. In our study, bone marrow cells showed comparable cell counts after infection between $S$. aureus and group control and a reduced number of cells for the E. coli group. In mice, the bone marrow reserve is estimated to be 120 million cells, while the total number of neutrophils in the circulation of a naïve mouse is between 2 and 5 million. As such, the rapid egress of neutrophils from the bone marrow reserve may increase circulating numbers by 10 -fold within a matter of hours. Mobilization from the bone marrow therefore represents a critical step in the trafficking of neutrophils to sites of inflammation [26]. In the bone marrow, macrophages have been described as an important source of cytokines and provide the necessary contact between the cells to hematopoiesis and lymphopoiesis [27].

Leukocytes present in the connective tissues were evaluated quantitatively after 24 hours of infection. The results showed that the number of cells was higher in group S. aureus. Several studies report that neutrophils are rapidly recruited to sites of infection where they bind and internalize invading $S$. aureus, and this process triggers potent oxidative and non-oxidative antimicrobial killing mechanisms that serve to limit pathogen survival and dissemination [28]. 
In our case, we may state that $S$. aureus induces more exacerbated local response than the $E$. coli group. Although some studies like the one conducted by Arreto et al.(1997), observed that the lipopolysaccharide induces the resident macrophages in the pocket lining to produce chemotactic substances with the consequent recruitment of neutrophils [29]. Other authors have reported that the survival of $S$. aureus into various cells, including phagocytes, has been proposed as a mechanism for the persistence of the microorganism on certain types of infections, including the ability to modulate the normal circulation of neutrophils, a key process for the resolution of acute inflammation [30].

Compared with the control group, total and differential cell counts in the lavages, we observed a greater number of cells in group infected by $S$. aureus, confirming the previous findings. These chemotactic signals directing movement from circulation to sites of injury or infection of the tissues is related to surface components, such as lipoteichoic acid present in $S$. aureus. In addition, some studies have reported that lymphocytes stimulated with capsular polysaccharides produce cytokines that recruit neutrophils to sites of infection, demonstrating the variety of different types of cells that play a major role in the inflammatory response elucidation [28].

Pro activity and IFN- $\gamma$ the anti-inflammatory is important to balance the immune response. IFN $-\gamma$ orchestrates the attraction of leukocytes, stimulates macrophages and directs the growth, maturation and differentiation of many cell types such as natural killer cells [31]. In our data we observed that the production of this cytokine in infected animals was higher compared with the control group. Some studies as proposed by Kamijo et al.(1993), reported the importance of IFN- $\gamma$ in response to initiation of macrophages as well as other studies indicate that pretreatment with IFN- $\gamma$ is required for induction of certain genes in response to lipopolysaccharide [32].

\section{CONCLUSION}

In summary, based on the assessment of the inflammatory response, it is clear that $S$. aureus induces a prominent local flow cell characterized by increased presence of neutrophils and macrophages. S. aureus has evolved an abundant repertoire of factors aimed at evasion of the innate system, including host defense strategies utilized by neutrophils, addition to attempts to modifying the bacterial surface. This is afforded by production of exopolymers such as capsular polysaccharide or polysaccharide intercellular adhesion.

The 24 hour period evaluated for infection with $E$. coli is premature to determine if there was a systemic response. Some studies indicate that prolonged exposure to lipopolysaccharide results in the release of several inflammatory mediators, including those which are released by monocytes / macrophages and granulocytes. Future studies should deepen understanding of the cellular recruitment induced by pathogens with different cellular structures.

1. Amir LH, Harris H, Andriske L. An audit of mastitis in the emergency department. J Hum Lact. 1999;15:221-224.

2. Foster TJ. Immune evasion by Staphylococci. Nat Rev Microbiol. 2005;3(12):948-958.

3. Kawai TAS. The role of pattern-recognition receptors in innate immunity: update on Toll-like receptors. Nat immunol. 2010; 11:373-384.

4. Kaper JB, Nataro JP, Mobley HLT. Pathogenic Escherichia coli. Nat Rev Microbiol. 2004;2:12340.

5. Russo TA, Johnson JR. "Proposal for a new inclusive designation for extraintestinal pathogenic isolates of Escherichia coli: ExPEC,”. Jpn j infect dis. 2000;181(5):1753-1754.

6. Trautner, b.w., hull, r. A. And darouiche, r. O. "Escherichia coli 83972 inhibits catheter adherence by a broad spectrumofuropathogens,”. Urology. vol. 61, no. 5, pp. 1059-1062. (2003).

7. Medzhitov R. Origin and physiological roles of inflammation. Nature. 2008;454(7203):428-35.

8. Lekstrom-himes JA, Gallin JI. Immunodeficiency diseases caused by defects in phagocytes. NEJM. 2000;343:1703-1714.

9. Rosen H, Klebanoff SJ. Bactericidal activity of a superoxide anion-generating system. A model for the polymorphonuclear leukocyte. JEM. 1979;149:27-39. 
10. Weissman IL, Anderson DJ, Gage F. Stem and progenitor cells: origins, phenotypes, lineage commitments, and transdifferentiations. Annu Rev Cell Dev Bi. 2001;17:387-403.

11. Rosenbauer F, Tenen DG. Transcription factors in myeloid development: balancing differentiation with transformation. Nat Rev Immunol. 2007;7(2):105-117.

12. Theilgaard MK, Jacobsen LC, Borup R, Rasmussen T, Bjerregaard MD, Nielsen FC, Cowland JB, Borregaard $\mathrm{N}$. The transcriptional program of terminal granulocytic differentiation. Blood. 2005;105(4):1785-1796.

13. de Leo FR, Diep BA, Otto M. Host defense and pathogenesis in Staphylococcus aureus infections. Infect dis clin $n$ am. 2009;23(1):17-34.

14. Santini M, Kutles AM, Pangercic A, Barsic B. The importance of pathogens in sepsis: Staphylococcus aureus story. Scand j infect dis. 2010;42(3):172-6.

15. Xing J, Moldobaeva N, Birukova AA. Atrial natriuretic peptide protects against Staphylococcus aureus-induced lung injury and endothelial barrier dysfunction. J Appl Physiol. 2011;110(1):21324.

16. Mosser DM, Edwards JP. "Exploring the full spectrum of macrophage activation," Nat Rev Immunol. 2008;8(12):958-969.

17. Biswas SK, Mantovani A. "Macrophage plasticity and interaction with lymphocyte subsets: cancer as a paradigm," Nat immunol. 2010;11(10):889-896.

18. Medzhitov R, Schneider DS, Soares MP. Disease tolerance as a defense strategy. Science. 2012;335:936-41.

19. Edwards JC, Sedgwick AD, Willoughby DA. The formation of a structure with the features of synovial lining by subcutaneous injection of air: an in vivo tissue culture system. The Journal of Pathology. 1981;134(2):147-56.

20. Sedwick A, Sin, Y, Edwards J, Willoughby D. Increased inflammatory reactivity in newly formed ligning tissue. The Journal of Pathology. 1983;198:483-95.

21. Mcfarland J. The nephelometer: an instrument for estimating the numbers of bacteria in suspensions used for calculating the opsonic index and for vaccines. JAMA. 1907;49:1176-1178.

22. Edwin S, Van A, Theo JC, Van B, Johan K. Receptors, Mediators, and Mechanisms Involved in Bacterial Sepsis and Septic Shock. Clin Microbiol Rev. 2003;16(3):379-414.

23. Maciej L, Hans-Joachim A. Macrophages and fibrosis: How resident and infiltrating mononuclear phagocytes orchestrate all phases of tissue injury and repair. Bba-mol basis dis. 2013; 1832(7):989997.

24. Asehnoune K, Strassheim D, Mitra S, Kim JY, Abraham E. Involvement of reactive oxygen species in Toll-like receptor 4-dependent activation of NF-kappa B. J immunol. 2004;172(4): 2522-9.

25. Vadiveloo PK, Vairo G, Hertzog P, Kola I, Hamilton JA. Role of type I interferons during macrophage activation by lipopolysaccharide. Cytokine. 2000;12:1639-1646.

26. Scott DK, Kevin RB, Amy MP-B, Adam DK, Elizabeth S, Ervand K, Adeline R, Daniel ES, David WD, Steven MH, Barry NK, James MM, Frank RD. Bone Marrow Chimeras and c-fms Conditional Ablation (Mafia) Mice Reveal an Essential Role for Resident Myeloid Cells in Lipopolysaccharide/TLR4-Induced Corneal Inflammation. Journal Innate Immunity. 2010;2:560575 .

27. Wang JE, Jorgensen PF, Almlof M, Thiemermann C, Foster SJ, Aasen AO, Solberg R. Peptidoglycan and lipoteichoic acid from Staphylococcus aureus induce tumor necrosis factor alpha, interleukin 6 (IL-6), and IL-10 production in both T cells and monocytes in a human whole blood model. Infect immun. 2000;68:3965-3970.

28. Rigby KM, Deleo FR. Neutrophils in innate host defense against Staphylococcus aureus infections. Semin immunopathol. 2012;34(2):237-59.

29. Arreto CD, Dumarey M-A, Nahori C, Vargaftig BB. The LPS-induced neutrophil recruitment into rat air pouches is mediated by TNF $\alpha$ : likely macrophage origin. Mediat inflamm. 1997;6(5-6), 335343.

30. Simor A, Daneman N. "Staphylococcus aureus decolonization as a prevention strategy" Infect Dis Clin N Am. 2009;23:134-151.

31. Pugin J, Schurer-Maly CC, Leturcq D, Moriarty A, Ulevitch RJ, Tobias TS, Lipopolysaccharide activation of human endothelial and epithelial cells is mediated by lipopolysaccharide-binding protein and soluble CD14. PNAS. 1990;90: 2744-2748.

32. Kamijo RL, Le J, Shapiro D, Havell EA, Huang S, Aguet M, Bosland M, Vilcek J. Mice that lack the interferon-gamma receptor have profoundly altered responses to infection with Bacillus Calmette-Guérin and subsequent challenge with lipopolysaccharide. JEM. 1993;178(4):1435-40. 